\title{
How to get rid of ingested microplastic fibers? A straightforward approach of the Atlantic ditch shrimp Palaemon varians ${ }^{\text {h }}$
}

\author{
Reinhard Saborowski * Eva Paulischkis , Lars Gutow \\ Alfred Wegener Institute, Helmholtz Centre for Polar and Marine Research, Am Handelshafen 12, 27570 Bremerhaven, Germany
}

\section{A R T I C L E I N F O}

Article history:

Received 19 March 2019

Received in revised form 7 August 2019

Accepted 15 August 2019

Available online xxx

Keywords:

Shrimp

Fibers

Beads

Regurgitation

Defecation

Retention

\begin{abstract}
A B S T R A C T
Microplastic fibers represent a significant share of the global marine micrcroplastic pollution, particularly in coastal areas. In controlled laboratory experiments, we offered fluorescent microplastic fibers $(40-4400 \mu \mathrm{m}$ lengths, median $150 \mu \mathrm{m})$ and spherical microplastic beads $(9.9 \mu \mathrm{m} \varnothing)$ together with commercial fish food to the Atlantic ditch shrimp Palaemonetes varians. The shrimps ingested fibers and beads along with the food. Upon ingestion, the beads and the shortest fibers (up to $100 \mu \mathrm{m}$ ) passed from the stomach into the gut and were egested within the fecal strings. The longer fibers first remained in the stomach but were regurgitated, i.e. extruded through the esophagus, within $12-14 \mathrm{~h}$. Regurgitation is an evolutionary adaptation of particular crustacean species and other invertebrates to remove large and indigestible food particles from the stomach. Accordingly, the process of regurgitation attained a new task nowadays, i.e. the elimination of anthropogenic filamentous microplastic debris from the stomach to avoid harm. This behavioral feature may represent a selective advantage in view of the continuously increasing environmental plastic pollution.
\end{abstract}

\section{Introduction}

An estimated eight million metric tons of plastic waste enter the oceans every year and a further increase by one order of magnitude until 2025 is predicted (Jambeck et al., 2015). In natural environments, plastic items disintegrate due to mechanical action, UV-radiation, or thermo-oxidation, thereby bearing numerous small fragments (Barnes et al., 2009; Andrady, 2011; Cole et al., 2011; ter Halle et al., 2016; Weinstein et al., 2016). Microplastic particles can be ingested by a variety of organisms including small invertebrates. The effects of microplastic ingestion are, however, inconclusive. Various studies showed that particles pass the digestive tract without detectable effects on organisms (e.g. Hämer et al., 2014; Kaposi et al., 2014; Santana et al., 2018; Weber et al., 2018) whereas other studies reported damage to organs, tissues, and cells at experimentally administered particle concentrations ofup to $20 \mathrm{mg} \mathrm{L}^{-1}$ (Jeong et al., 2016, 2017) or $2.5 \mathrm{gL}^{-1}$ (von Moos et al., 2012).

Besides irregular fragmented particles, synthetic fibers constitute a significant share of microplastics in the environment, often outnumbering other types of particles, such as fragments and beads. In the brackish waters of the Baltic Sea off Sweden, microfibers accounted for more than $80 \%$ of the overall collected microplastics, accounting for about four fibers per cube meter (Gewert et al., 2017). Mathalon and Hill (2014) found 20 to 80 plastic fibers in $10 \mathrm{~g}$ of sediment at a beach in the Halifax region (Canada). The fibers probably originated

\footnotetext{
This paper has been recommended for acceptance by Maria Cristina Fossi.

* Corresponding author.

Email address: Reinhard.Saborowski@awi.de (R. Saborowski)
}

from domestic washing (reviewed by Salvador Cesa et al. (2017)) or from ropes or fishing nets. De Falco et al. (2018) reported up to $6,000,000$ fibers with a length of $300-500 \mu \mathrm{m}$, released from a typical $5 \mathrm{~kg}$ wash load of polyester fabrics. Napper and Thompson (2016) estimated a release of more than 700,000 fibers from a $6 \mathrm{~kg}$ wash load of acrylic fabric. Mason et al. (2016) estimated an average daily discharge of 4 million microplastic fibers by each single municipal wastewater treatment plant in the US states of California, New York, Wisconsin, and Ohio. Additionally, fishing gear and ropes, whether in use, lost, or discarded, also significantly contribute to environmental pollution by microplastic fibers (e.g. Barnes et al., 2009; Macfadyen et al., 2009; Cole et al., 2011).

Different to irregular or spherical particles, fibers are widely disregarded in environmental and ecotoxicological studies because it is difficult to differentiate between environmental contaminants and accidently introduced fibers during sample processing in the field and in the laboratory. So far, however, presence of fibers was reported in various species of seafood (Rochman et al., 2015). Blue mussels were examined for their suitability to monitor microplastic pollution in Norwegian coastal waters where mussels contained on average $1.5 \mathrm{mi}$ croplastics per individual (Bråte et al., 2018). Overall, 83\% of the particles investigated in that study were fibers. Synthetic fibers were detected in $63 \%$ of assessed brown shrimp from the coastal waters of the Southern North Sea and the Channel (Devriese et al., 2015). Desforges et al. (2015) found that the share of ingested microplastic fibers of the total microplastic particles in Euphausia pacifica in the NE Pacific decreased with distance from shore suggesting substantial discharge of synthetic fibers from land-based sources.

Upon ingestion, the fibres may provoke false satiation in animals, either when applied at high concentrations or when they accumulate 
over time in the stomachs as observed in Norway lobster, Nephrops norvegicus (Murray and Cowie, 2011; Welden and Cowie, 2016a, 2016b). The water flea, Daphnia magna, readily ingested plastic fibers of $300 \mu \mathrm{m}$ average length but also very long fibers of around $1,400 \mu \mathrm{m}$ (Jemec et al., 2016). Mortality increased when the animals were exposed to plastic fibers only, but not when they were fed with natural food prior to plastic exposure. The amphipod Hyalella azteca was exposed to polyethylene microplastic particles and polypropylene microplastic fibers. Fibers caused significantly higher mortality than particles (Au et al., 2015). The higher toxicity of the fibers corresponded with longer residence time of the fibers in the gut, which, in turn, might have affected the ability to process food and led to severe energetic deficiency (Au et al., 2015).

The present study aims at investigating whether microplastic fibers and beads are ingested by the Atlantic ditch shrimp Palaemon varians and how they are translocated within the digestive organs of the shrimp. $P$. varians was chosen as test organism because these shrimps are common in coastal regions and estuaries of the Northeast Atlantic where they are particularly exposed to domestic and industrial environmental plastic pollution (Browne, 2015). The animals are relatively small (1-3 cm in length) and widely translucent allowing for direct observation of ingested fluorescent fibers and particles in living animals under a fluorescence stereomicroscope. To clearly observe the fibers and beads, and to track their position in the shrimp, we applied in this study high concentrations well above the environmental levels. We addressed the following questions: 1) do these shrimps ingest microplastic fibers and particles, 2) do the plastic fibers accumulate in the stomach, and 3) and do they cause mortality at the applied experimental conditions?

\section{Methods}

\subsection{Origin of organisms}

Atlantic ditch shrimps (Palaemon varians, Leach 1813) were either purchased from an aquaristic shop (Futterhaus, Bremerhaven, Germany) or were captured with a hand net in a semi-enclosed former harbor basin in the city of Bremerhaven (Holzhafen; 53 $32.177820^{\prime}$ $\left.\mathrm{N}, 8^{\circ} 35.503680^{\prime} \mathrm{E}\right)$. The shrimps were immediately transferred to the laboratories of the Alfred Wegener Institute, where they were maintained in $10-\mathrm{L}$ aquaria in brackish water of $15 \mathrm{PSU}, 15^{\circ} \mathrm{C}$, and $16: 8 \mathrm{~h}$ of indirect illumination and darkness. The shrimps were fed every other day with plant-based fish food (NovoVert, JBL) and, additionally, once a week with freshly hatched Artemia sp. nauplii (Great Salt Lake Artemia Cysts, Sanders). The water was exchanged each day after feeding. Animals from both sources were used for preliminary experiments. The feeding experiments reported in this study were solely performed with animals from the urban pond.

\subsection{Fluorescent fibers and microbeads}

Small plastic fibers were cut from fluorescent polyacrylic wool "Magic Leucht Wolle fluo grün" (Magic Pyramid Bruecher \& Partner KG, Frechen, Germany, No. 839512) by hand with scissors under a stereomicroscope. A sample of $0.5 \mathrm{mg}$ contained almost 3000 fibers. The lengths of the fibers ranged between 40 and $4400 \mu \mathrm{m}$. The average length was $236 \pm 176$ (SD) $\mu \mathrm{m}$, the median length was $189 \mu \mathrm{m}$ (Fig. 1), and the width of the fibers was $30-35 \mu \mathrm{m}$. Due to electrostatic adhesion and their high numbers, fibres could not be counted properly. Instead, the administered quantity in the experiments was expressed by mass. Fluorescent microbeads of polystyrene (PS, Flu-

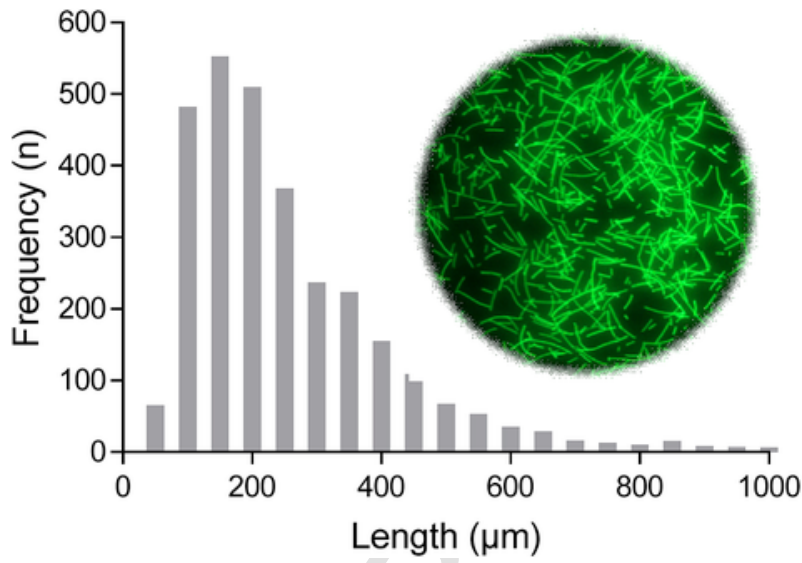

Fig. 1. Length distribution and appearance of fluorescent fibers after production and before administration to the test organisms.

oro-Max $^{\mathrm{TM}}$ Green Fluorescent Microspheres, 9.9 $\mu \mathrm{m}$ diameter) were purchased from Thermo Fisher Scientific. They were delivered in a suspension of $1 \%$ solids in water at a concentration of $20,000 \mathrm{mi}-$ croplastics (MP) $\mu \mathrm{L}^{-1}$. The fibres and the beads were observed under a fluorescence stereomicroscope (Nikon Instruments, SMZ25) with FITC fluorescence filter (ex: $494 \mathrm{~nm}$; em: $518 \mathrm{~nm}$ ). Photographs were taken with a Nikon camera DS-Ril and attendant software (NIS-Elements Basic Research 4.20.01), which also included features for length measurements that we used for the fibres.

\subsection{Experimental procedure}

The animals were acclimated to room temperature $\left(22^{\circ} \mathrm{C}\right)$ which was similar to the ambient water temperatures at the time the shrimps were collected $\left(22-24^{\circ} \mathrm{C}\right)$. Prior to the experiments, the test animals were starving for $48 \mathrm{~h}$ to void their stomachs from remaining food. The water was exchanged daily to prevent coprophagia. The fullness of the stomachs of the translucent shrimps was visually estimated under the stereo microscope. Only shrimps with empty stomachs were used for the feeding experiments.

\subsection{Ingestion of fibres, beads, and food (Exp.1)}

Animals received $0.5 \mathrm{mg}$ of plastic fibres and four quantities of flake food (NovoVert, JBL): $0 \mathrm{mg}, 2.5 \mathrm{mg}, 5 \mathrm{mg}$, and $10 \mathrm{mg}$ (see also Table S1). The fibres and the food were suspended in $100 \mathrm{ml}$ brackish water (15 PSU) which was previously filtered through a $0.1-\mu \mathrm{m}$ membrane filter. Animals were kept individually in the experimental units (beakers). Ten replicates were run in each of the four feeding experiments, accounting for 40 animals in total. The shrimps were incubated for $3 \mathrm{~h}$ with the food and the fibres. Thereafter, the animals were frozen at $-20^{\circ} \mathrm{C}$ for $10 \mathrm{~min}$. The wet weights and the lengths from the frontal edge of the eyes to the tip of the uropods were recorded. The stomach, the midgut gland, and the gut of each animal were screened with a fluorescence microscope for microplastic fibres. Subsequently, the organs were dissected and suspended in $100-200 \mathrm{ml}$ of dist. water. The fibres were counted and their lengths were measured under a fluorescence binocular.

\subsection{Stomach residence time of microplastic fibers and beads (Exp. 2)}

A preliminary feeding experiment showed that the digestive organs (stomach, midgut gland, gut) of $P$. varians were void of microfibers after $24 \mathrm{~h}$. Therefore, we ran an experiment to estimate the 
residence times of food, fibres, and beads. Animals were starved for $48 \mathrm{~h}$ prior to the experiment. The maintenance water was exchanged repeatedly and only shrimps with empty stomachs were selected for the experiments. Preliminary observations also showed that $P$. varians ingested fibres more eagerly when they were attached to food items. Therefore, a blend was prepared consisting of $5 \mathrm{mg}$ of flake food, $1 \mathrm{mg}$ of fibres, and $10 \mu \mathrm{L}$ of 1:10 diluted solution of beads per portion. The control food contained $5 \mathrm{mg}$ of flakes and $10 \mu \mathrm{l}$ of demineralised water. The food preparations dried overnight at room temperature. Care was taken during the procedure to avoid contamination of the food. The following day, 200-mL petri dishes were filled with $100 \mathrm{ml}$ filtered brackish water (15 PSU) and the prepared food was added with metal forceps. Each of the petri dishes contained about 200,000 beads $\mathrm{L}^{-1}$ and $5 \mathrm{mg}$ of fibres as estimated from the amount of food blend added to the water. The animals were placed into the petri dishes and allowed to feed for $20 \mathrm{~min}$. Subsequently, the animals were inspected under the fluorescent microscope for ingested fibres, beads, and food. If the stomachs contained microplastics, the animals were transferred into dishes with $100 \mathrm{ml}$ of fresh and filtered brackish water. Every $2 \mathrm{~h}$, the animals were inspected again and the following parameters were recorded: a) presence of food and microplastics in the digestive organs, b) amount of feces in the petri dish, c) presence of fibres and beads in the feces, and d) presence of mucus plaques at the bottom of the petri dish. After each inspection, the water in the petri dishes was exchanged to enable observation of newly produced feces which was egested during the following $2 \mathrm{~h}$. In total, 27 animals were tested: 9 control animals and 18 fed with beads and fibres. The residence time of fibres was estimated in all 18 animals and the residence time of beads and food in 9 of the 18 animals. See also Table S1.

\subsection{Survival}

To investigate whether microplastic ingestion had adverse effects on $P$. varians, the survival of the shrimps was recorded for another $48 \mathrm{~h}$. After the experiments were terminated, the animals were continuously fed with flakes (without microplastics) to prevent fatal starvation. Signs of vitality were upright position of the animal, locomotion, and a translucent appearance of the body.

\subsection{Stomach movement and regurgitation}

Time-lapse recordings were carried out to observe the stomach peristaltic and the egestion of the fibres and beads. Shrimps were fed with food containing fibres and beads as described above. The lateral side of the cephalothorax of the animals was shortly blotted dry with tissue paper and the animals were fixed with a two-component epoxy resin adhesive (UHU, 2-komponenten Epoxidharzkleber) onto the bottom of a petri dish. The dish was filled with brackish water and the animals were observed for $10 \mathrm{~h}$ under the fluorescence stereo microscope. Photographs were taken every $10 \mathrm{~s}$ with the software program NIS Elements.

\subsection{Data analysis}

Statistical analysis of data and preparation of graphs was done with the software package GraphPad Prism 7.05 for Windows (GraphPad Software, La Jolla California USA, www.graphpad.com). Data sets were analyzed for normal distribution and equal variances. Outliers were identified by the ROUT method. Since data sets were not normally distributed, comparison between groups was performed with sqrt-transformed data, one way ANOVA, and Dunnett's multiple comparison post-hoc test.

The stomach residence times were fitted to the Boltzmann sigmoidal equation:

$$
Y=Y_{\min }+\frac{\left(Y_{\max }-Y_{\min }\right)}{1+\exp \left[\frac{V_{50}-X}{\text { Slope }}\right]}
$$

The half-times of the stomach evacuation $\left(\mathrm{V}_{50}\right)$ and their standard errors (SE) were calculated and compared between animals fed with regular food (control group), microplastic fibers, and microplastic beads, and a mix of microplastic fibres, beads, and food. Treatments with overlapping standard errors $\left(\mathrm{V}_{50} \pm \mathrm{SE}\right)$ were considered not significantly different from each other.

\section{Data availability}

All data supporting the finding of this study are deposited in the Pangea data library. Additionally, information is available from the corresponding author upon reasonable request.

\section{Results}

\subsection{Acceptance of microplastic fibers and beads and their distribution in the digestive organs of shrimps}

The length of the shrimps Palaemon varians used in this study ranged between 14 and $36 \mathrm{~mm}$ and their masses between 88 and $490 \mathrm{mg}$. Fluorescent acrylic fibers and microspheres were ingested by the shrimps (Fig. 2a). Fibers and microspheres were present in $75 \%$ of the stomach from shrimps deployed in Exp. 1. The lengths of the fibers in the stomach ranged from 26 to $2088 \mu \mathrm{m}$ ( $236 \pm 176 \mathrm{SD})$, re-
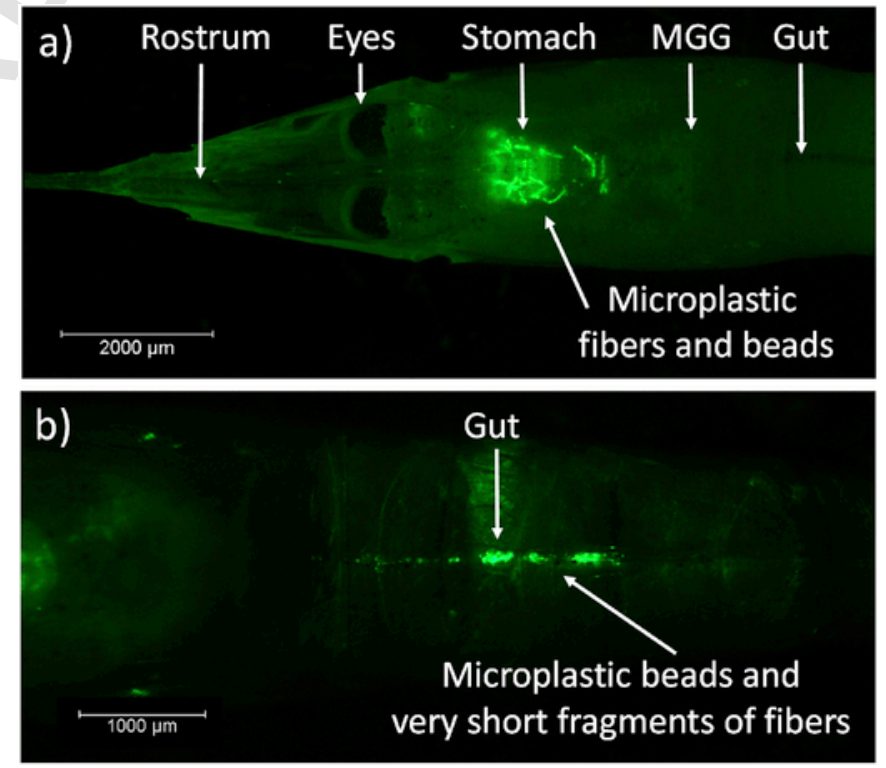

Fig. 2. Dorsal view of a) the cephalothorax and b) the abdomen of the shrimp P.varians. The stomach within the cephalothorax is filled with fluorescent fibers and beads. The midgut gland (MGG) posterior to the stomach appears dark and does neither contain fibers nor beads. The gut within the abdomen contains beads and very short fragments $(<100 \mu \mathrm{m})$ of the microplastic fibers. 
flecting the size range of the administered fibers. No fibers and no microspheres were observed in the midgut glands. Only microspheres and very small fragments of fibers $(<100 \mu \mathrm{m})$ were present in the gut (Fig. 2b). After $24 \mathrm{~h}$ the stomachs were void of fibers and beads. Likewise, no microplastics were present in the guts and in the midgut glands.

\subsection{Ingestion of fibers at different food concentrations (Exp. 1)}

Animals, which received $0.5 \mathrm{mg}$ of plastic fibers and no food, contained 0 to 8 particles (median 0.5 fibers per animal) in their stomachs after $3 \mathrm{~h}$ of exposure (Fig. 3). Ingestion of fibers differed significantly with food concentrations (ANOVA, $\mathrm{F}_{3,33}=4.733, \mathrm{p}=0.0074$ ). When animals were fed with $2.5 \mathrm{mg}$ of commercial food containing microplastics, the uptake of fibers increased significantly to up to 47 fibers (median: 16.5, $\mathrm{p}=0.0027$ ). Further increase of food to $5 \mathrm{mg}$ reduced the uptake of fibers to maximally 32 items (median: 15) which, however, was still significantly higher than ingestion of fibers of animals without food $(\mathrm{p}=0.0395)$. At $10 \mathrm{mg}$ of food, up to 17 items were ingested (median: 8) which was not significantly different from the unfed animals $(p=0.1374)$. Three individuals ingested exceptional amounts of fibers of 146, 1176, and 1469 items per animal, respectively. These data were identified as outliers and not considered in the statistical comparison nor in the graphical presentation of the results.

\subsection{Stomach residence time of microplastic fibers and beads (Exp. 2)}

Gut evacuation of the shrimps followed a sigmoidal function. The coefficient of determination varied between $\mathrm{R}^{2}=0.9981$ for food alone (Fig. 4a) and $\mathrm{R}^{2}=9.9883$ for fibers, $\mathrm{R}^{2}=0.9714$ for beads, and $\mathrm{R}^{2}=0.9519$ for the entire mixture of food, fibers, and beads (Fig. 4b). Food remained in all stomachs for the first $4 \mathrm{~h}$ but all stomachs were evacuated within $12 \mathrm{~h} .50 \%$ of stomach evacuation was reached after $8.39 \pm 0.13 \mathrm{~h}$ (Fig. 4a). Fibers were evacuated from the stomach most rapidly (Fig. 4b). Already after $2 \mathrm{~h}$, the first stomachs were void of fibers. After $6.96 \pm 0.55 \mathrm{~h}, 50 \%$ of the animals had no fibers in their stomachs. Thereafter, the animals continuously emptied their stomachs within about $12 \mathrm{~h}$. Beads were evacuated from the stomach at a similar rate as food. Half of the animals showed empty stomachs after

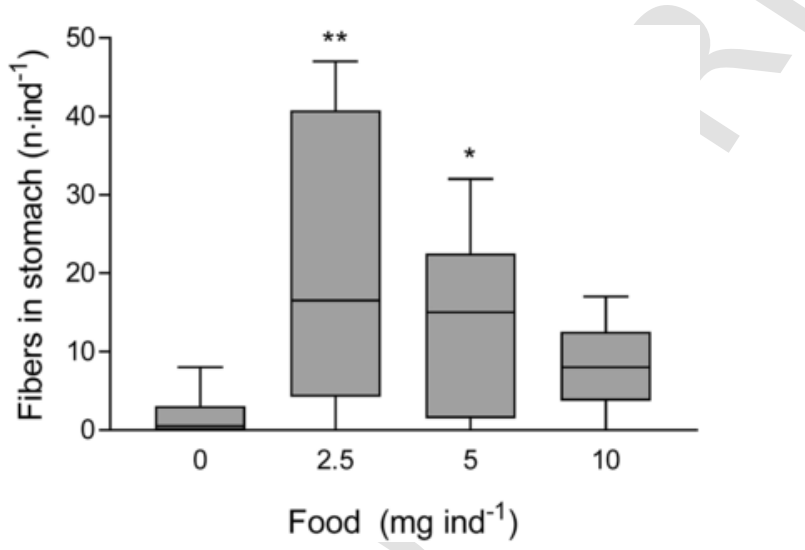

Fig. 3. Numbers of ingested plastic microfibers in stomachs of Palaemon varians, which were offered $0.5 \mathrm{mg}$ of microplastic fibres and variable amounts of commercial food $(0,2.5,5,10 \mathrm{mg})$ in $100 \mathrm{ml}$ of water. Box plots show median, 25 th and 75 th percentile, minimum and maximum values. Asterisks indicate significant differences between animals, which were not fed and those which received 2.5 and $5 \mathrm{mg}$ of food, respectively (ANOVA and Dunnett's multiple comparison on sqrt-transformed data, $\mathrm{p}<$ $0.05(*), \mathrm{p}<0.01(* *), \mathrm{n}=8-10)$.

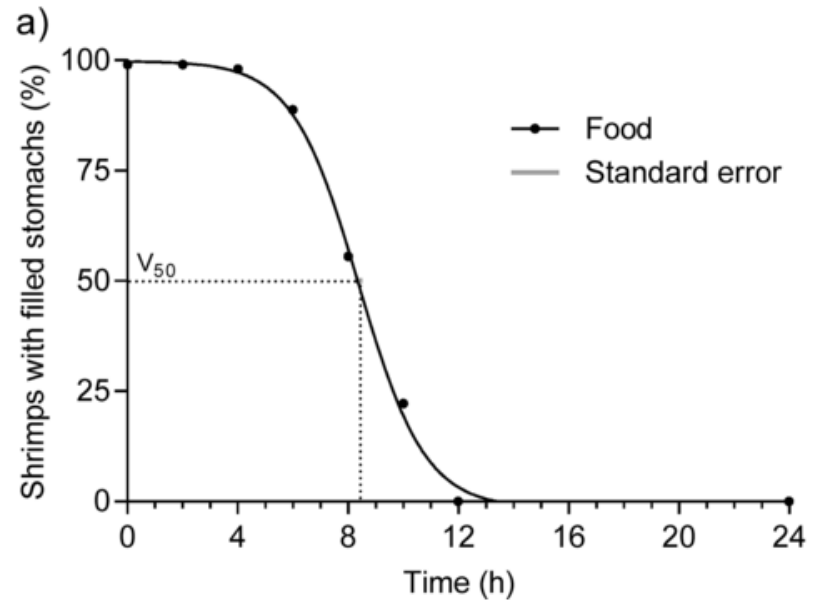

b)

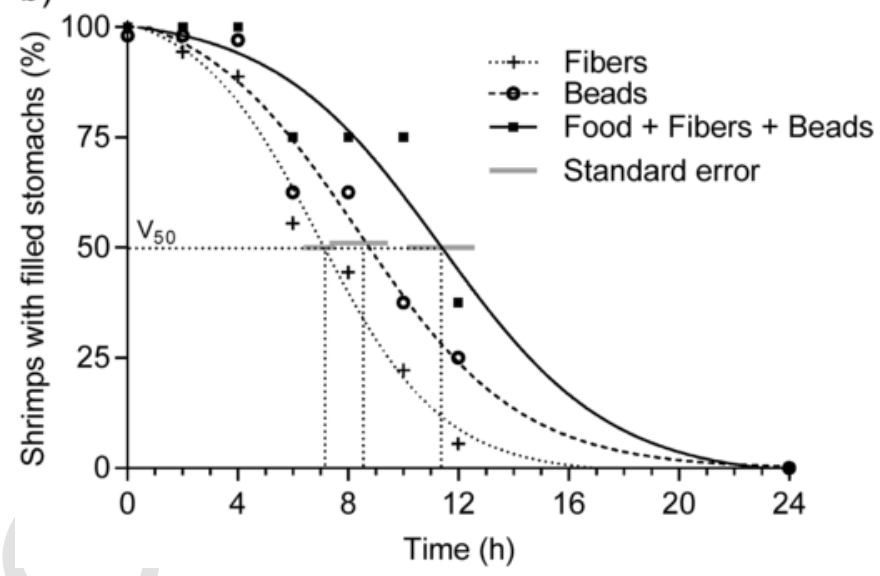

Fig. 4. Evacuation of a) food and b) plastics and food from shrimp stomachs. After feeding, animals were inspected for the presence of food and/or plastics in their stomachs. The share $(\%)$ of animals with filled stomachs was plotted against the time. The times at which $50 \%$ of the stomachs were empty $\left(\mathrm{V}_{50}\right)$, and their standard errors, served as measure to compare evacuation times. Overlapping standard error indicate no significant difference between $V_{50}$ of different treatments. The standard error bar in Fig. $4 \mathrm{a}$ is smaller than the size of the symbols in the graph. a) 9 shrimps were deployed and analyzed $(n=9)$. b) 18 shrimps were deployed and $n=18$ were analyzed for fibers, $\mathrm{n}=9$ were analyzed for beads, $\mathrm{n}=9$ were analyzed for the entire stomach content (fibers, beads, and food).

$8.38 \pm 1.05 \mathrm{~h}$ but complete evacuation took more than $12 \mathrm{~h}$. Total evacuation of food, fibers and beads lasted longest. Half of the animals showed empty stomachs after $11.37 \pm 1.22 \mathrm{~h}$ (Fig. 4b). Evacuation $\left(\mathrm{V}_{50} \pm \mathrm{SE}\right)$ of fibers was significantly faster than evacuation of food. Evacuation of beads did not vary significantly from that of food. Evacuation of the mix of food, fibers, and beads lasted significantly longer than the evacuation of food alone.

\subsection{Survival}

The ingestion of fibers and microspheres did not seem to enhance mortality of the shrimps. Only one out of 18 animals (i.e. 5.6\%) died within $48 \mathrm{~h}$ of exposure.

\subsection{Egestion and regurgitation}

Most of the food remains and the microbeads were transferred from the stomach into the midgut and hindgut of the shrimp. Finally, they were egested as fecal strings, encased by a peritrophic mem- 
brane (Fig. 5). Besides microbeads, the fecal strings also contained some small fibers of about $100 \mu \mathrm{m}$ and less. The large fibers $(>100 \mu \mathrm{m})$ remained in the stomach but were cleared by regurgitation through the esophagus. Regurgitated material appeared as plaque-like mucous at the bottom of the aquaria (Fig. 6). It contained fluorescent fibers and undefined material, presumably food remains and gastric fluid. An example for a regurgitated plaque with various common airborne microplastic pollutants is presented in the Supplementary material (Fig. S1).

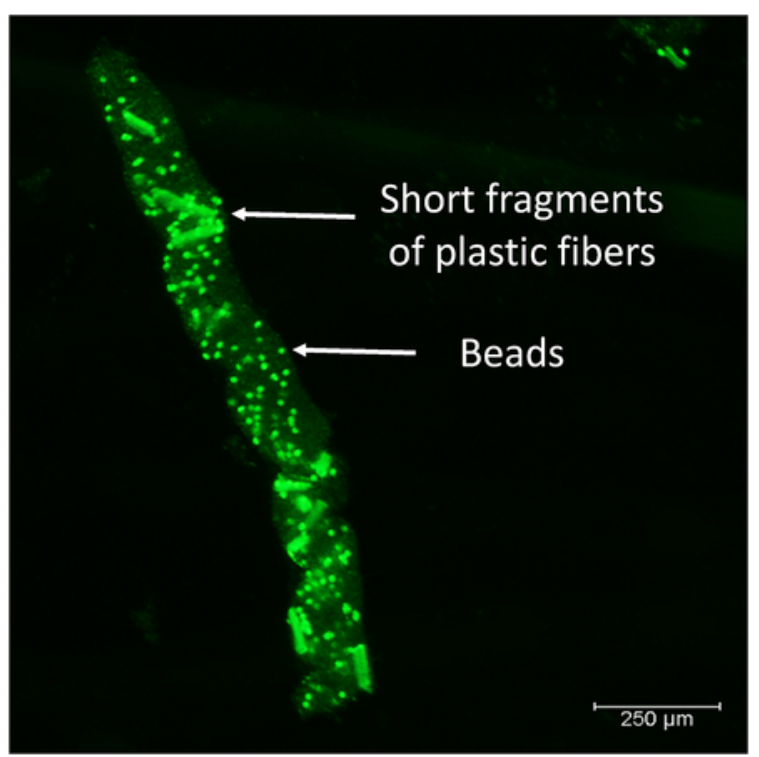

Fig. 5. A fecal string of Palaemon varians containing very short fragments of fluorescent microplastic fibers and beads. The fecal string is coated with a chitinous peritrophic membrane.

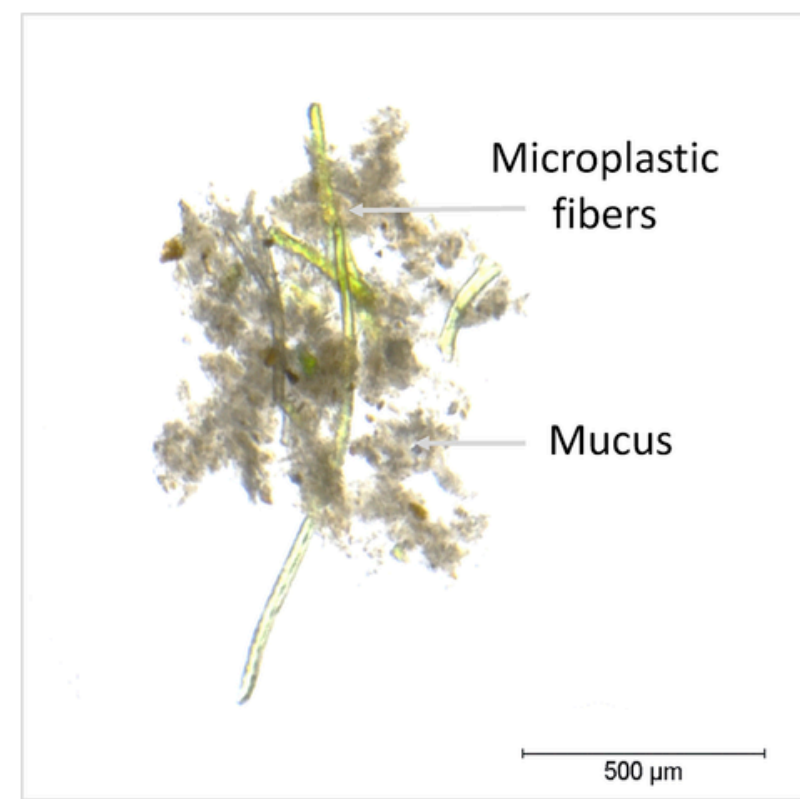

Fig. 6. Mucus-like plaque of regurgitated material at the bottom of the aquarium of animals fed with experimentally administered green microplastic fibers (MPFs) and food. (For interpretation of the references to color in this figure legend, the reader is referred to the Web version of this article.)
The process of regurgitation is shown in a time-lapse movie (Supplementary material). The fluorescent fibers were visible in the stomach (Fig. 7a). After contraction of the stomach, the fibers appeared in the esophagus (Fig. 7b). Fig. 7c and d show the release of the stomach content including fibers through the esophagus. Thereafter, the regurgitated material dispersed (Fig. 7e). Finally, the stomach was empty and few fluorescent particles remained attached to the setae of the mouthparts (Fig. 7f). The process of stomach evacuation lasted less than $3 \mathrm{~min}$.

Supplementary video related to this article can be found at https:// doi.org/10.1016/j.envpol.2019.113068.

\section{Discussion}

Fluorescent microplastic fibers and microspheres were ingested by the shrimps, Palaemon varians, preferably together with the offered food. The lengths of the fibers resemble those of fibers collected in the habitat of the shrimps, the brackish Baltic Sea waters off Sweden (290-2700 $\mu \mathrm{m}$, Gewert et al., 2017). The fibers were retained in the stomach while the microbeads were passed further into the gut. The latter were egested together with undigested food remains within fecal strings. After few hours, the fibers disappeared from the stomach as well and mucous plaques containing fluorescent fibers appeared at the bottoms of the aquaria in which the animals were maintained. The fibers were not egested through the gut, but left the stomach through the esophagus. This process has been reported previously as regurgitation.

Regurgitation is a common process in various invertebrates (Table 1). It is associated with e.g. defense behavior, food transfer among individuals, extracellular digestion, or defense suppression. In crustaceans, it has been described as a mechanism to remove large and hardly digestible food particles from the stomach. Already Forster and Gabbott (1971) reported that regurgitation of parts of the indigestible food remains after the meal complicated the accurate determination of assimilation efficiencies in the prawns Palaemon serratus and Pandalus platyceros. In the paddle crab Ovalipes catharus (Brachyura) shell fragments were cleared from the foregut by regurgitation after virtually all soft parts had been digested (Haddon and Wear, 1987). The speed of food procession and onset of regurgitation depended on temperature but not on animal size. At $20^{\circ} \mathrm{C}$, regurgitation happened within $3-6 \mathrm{~h}$, at $11^{\circ} \mathrm{C}$ within $11 \mathrm{~h}$, and at $9^{\circ} \mathrm{C}$ within $18 \mathrm{~h}$.

Even the pelagic pluteus larvae of the Pacific Sand Dollar, Dendraster excentricus, are able to regurgitate too large or offending particles from their esophagus by a reverse wave of peristaltic contractions (Burke, 1981). Kaposi et al. (2014) observed that the number of plastic particles ingested by the pluteus larvae of the sea urchin Tripneustes gratilla decreased with time. The authors suggested that the larvae recognized the low nutritional value of the plastic particles and rejected their ingestion or egested them over time. Another mechanism to select between digestible and indigestible food items is the formation of pseudofeces by certain bivalve species, such as the Blue mussel Mytilus edulis (Beninger and St-Jean, 1997; Beninger et al., 1999).

Apart from our laboratory experiments under controlled and clean conditions (Wesch et al., 2017) a few animals were left in an open uncontrolled area where they were exposed to the common airborne microplastics. These animals regurgitated plaque with various dark and blue-colored fibers (Fig. S1), which are most likely contaminants originating from clothes or other air-borne discharge. They resemble those fibers collected from the atmospheric fallout of urban environments or indoor facilities (Dris et al., 2016, 2017). This example, 

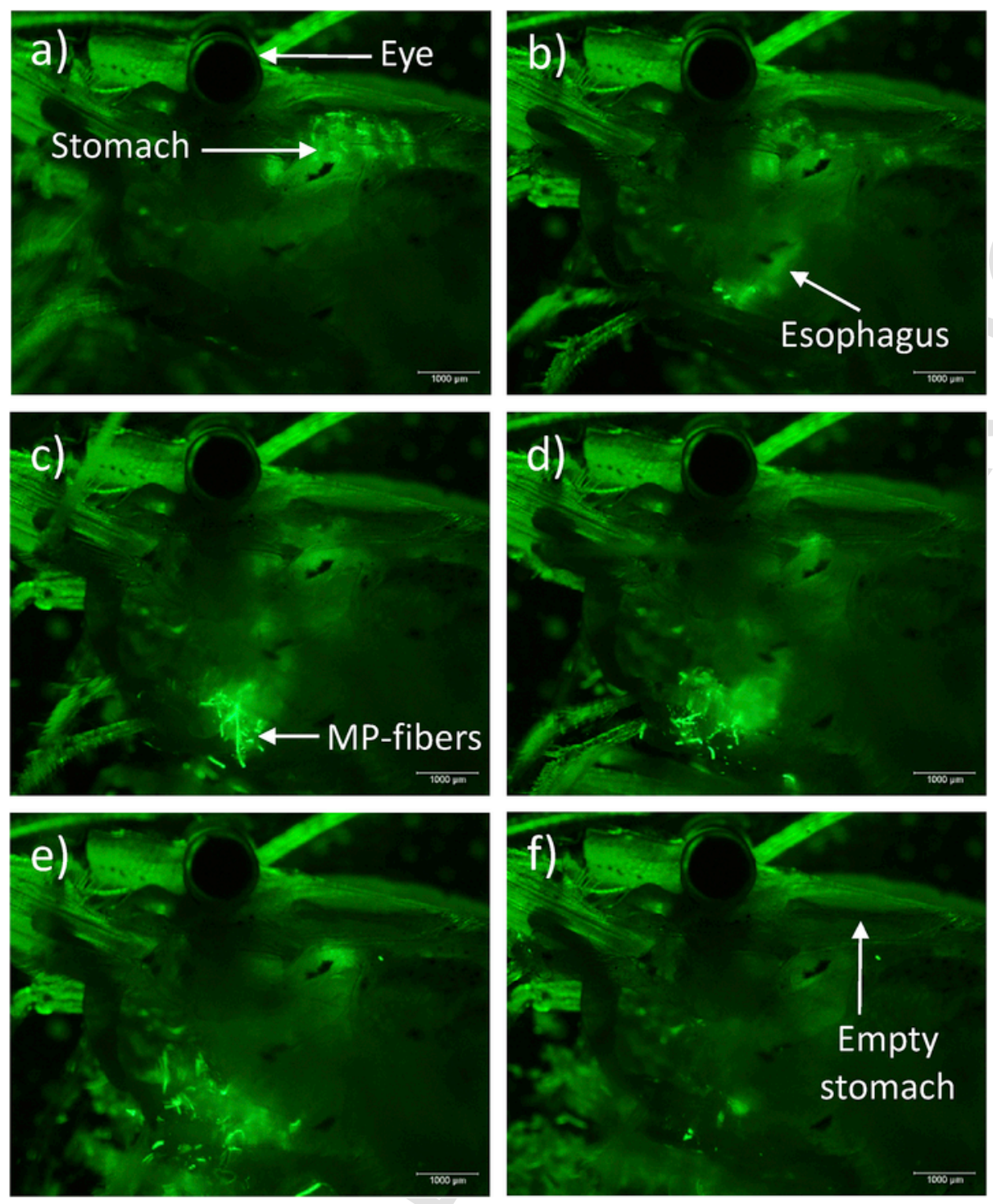

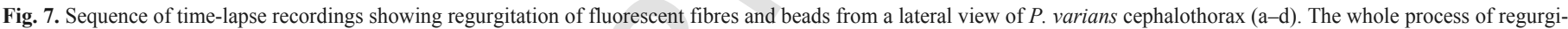
tation lasted $160 \mathrm{~s}$. Thereafter, the stomach of the shrimp was void of fibres and beads (e, f). MP-fibers $=$ microplastic fibres.

however, clearly demonstrates that the shrimps are also capable of regurgitating the meanwhile ubiquitously occurring microplastic contaminants.

The microplastic fibres used in our experiments had a similar shape as e.g. cellulose or lignin fibres. They were likely too large to be passed into the gut but were, instead, retained in the stomach and then regurgitated. However, when the animals received only food without microplastics, regurgitation also took place suggesting this behavior being no exclusive reaction to plastic contamination. An explanation for this behavior could be an adaptation of $P$. varians to the omnivorous, especially the herbivorous and detrivorous life style in particle-rich estuarine waters. In this way, the numerous indigestible organic and inorganic particles could be eliminated before injuring or clogging the digestive tract of the organism. Accordingly, the mortality of $P$. varians was low in our experiments. Only one animal died for unknown reason.

Different to $P$. varians, the closely related species Palaemonetes pugio, was not able to clear its digestive tract from polypropylene fibres after a $3 \mathrm{~h}$ exposure to 34 and $96 \mu \mathrm{m}$ long fibres (Gray and
Weinstein, 2017). As a result, $100 \%(34 \mu \mathrm{m})$ and $43 \%(93 \mu \mathrm{m})$ of the shrimps died within $96 \mathrm{~h}$. $P$. pugio lives in salt marshes at the Atlantic US coast of North America and, thus, encounters similar environmental and trophic conditions as P. varians. However, the ability to regurgitate fibres seems not to have evolved in this species. Similarly, the Norway lobster Nephrops norvegicus was shown to be unable to regurgitate indigestible items. Fibers accumulated in the stomach, formed small balls, and clogged the stomach. These balls could only be removed when the ectodermal structures of the stomach were shed off during moulting (Welden and Cowie, 2016a,b). Intermoult periods, however, lasted for several months during which animals showed signs of starvation due to the accumulation of the indigestible material in their stomachs. Besides filling the stomach with indigestible material, the microplastic particles may cause inflammation reactions and oxidative stress as shown in mollusks, rotifers, and copepods (von Moos et al., 2012; Jeong et al., 2016, 2017).

Although regurgitation has been described for several crustacean species, the anatomical requirements, the physiological control mechanisms, and the triggers for the regurgitation process are still un- 
Table 1

Crustaceans and other invertebrate species showing regurgitation.

\begin{tabular}{|c|c|c|c|}
\hline Species & Taxon & $\begin{array}{l}\text { Regurgitated } \\
\text { material }\end{array}$ & Reference \\
\hline Cancer pagurus & $\begin{array}{l}\text { Crustacea - } \\
\text { Brachyura }\end{array}$ & $\begin{array}{l}\text { Exoskeletal } \\
\text { fragments }\end{array}$ & $\begin{array}{l}\text { Lawton } \\
\text { (1989) }\end{array}$ \\
\hline Cancer gracilis & $\begin{array}{l}\text { Crustacea - } \\
\text { Brachyura }\end{array}$ & Food at low salinity & $\begin{array}{l}\text { McGaw } \\
(2006)\end{array}$ \\
\hline Cancer productus & $\begin{array}{l}\text { Crustacea - } \\
\text { Brachyura }\end{array}$ & $\begin{array}{l}\text { Not specified } \\
\text { stomach content }\end{array}$ & $\begin{array}{l}\text { McGaw } \\
(2007)\end{array}$ \\
\hline Ovalipes catharus & $\begin{array}{l}\text { Crustacea - } \\
\text { Brachyura }\end{array}$ & Shell fragments & $\begin{array}{l}\text { Haddon \& } \\
\text { Wear (1987) }\end{array}$ \\
\hline Scylla serrata & $\begin{array}{l}\text { Crustacea - } \\
\text { Brachyura }\end{array}$ & Shell fragments & Hill (1976) \\
\hline Palaemon serratus & $\begin{array}{l}\text { Crustacea - } \\
\text { Caridea }\end{array}$ & Cellulose fibers & $\begin{array}{l}\text { Fair et al. } \\
(1980)\end{array}$ \\
\hline Palaemon serratus & $\begin{array}{l}\text { Crustacea - } \\
\text { Caridea }\end{array}$ & Indigestible material & $\begin{array}{l}\text { Forster and } \\
\text { Gabbott } \\
(1971)\end{array}$ \\
\hline $\begin{array}{l}\text { Pandalus } \\
\quad \text { platyceros }\end{array}$ & $\begin{array}{l}\text { Crustacea - } \\
\text { Caridea }\end{array}$ & $\begin{array}{l}\text { Cellulose, lignin, } \\
\text { fragments of fish } \\
\text { scales and bones }\end{array}$ & $\begin{array}{l}\text { Forster and } \\
\text { Gabbott } \\
(1971)\end{array}$ \\
\hline Formica sanguinea & $\begin{array}{l}\text { Insecta - } \\
\text { Formicidae }\end{array}$ & Food exchange & $\begin{array}{l}\text { Wallis } \\
(1961)\end{array}$ \\
\hline Lasius flavus & $\begin{array}{l}\text { Insecta - } \\
\text { Formicidae }\end{array}$ & $\begin{array}{l}\text { Extracellular } \\
\text { digestion, defense }\end{array}$ & $\begin{array}{l}\text { Cammaerts } \\
\text { (1995) }\end{array}$ \\
\hline $\begin{array}{l}\text { Malacosoma } \\
\text { americanum }\end{array}$ & $\begin{array}{l}\text { Insecta - } \\
\text { Lepidoptera }\end{array}$ & $\begin{array}{l}\text { Enteric fluid for } \\
\text { defense }\end{array}$ & $\begin{array}{l}\text { Peterson et } \\
\text { al (1987) }\end{array}$ \\
\hline $\begin{array}{c}\text { Spodoptera } \\
\text { littoralis }\end{array}$ & $\begin{array}{l}\text { Insecta - } \\
\text { Lepidoptera }\end{array}$ & $\begin{array}{l}\text { Suppression of plant } \\
\text { defense }\end{array}$ & $\begin{array}{l}\text { Vadassery et } \\
\text { al. (2012) }\end{array}$ \\
\hline $\begin{array}{l}\text { Schistocera } \\
\text { emarginata }\end{array}$ & $\begin{array}{l}\text { Insecta - } \\
\text { Caelifera }\end{array}$ & $\begin{array}{l}\text { Gastric fluid for } \\
\text { defense }\end{array}$ & $\begin{array}{l}\text { Sword } \\
(2001)\end{array}$ \\
\hline Locusta migratoria & $\begin{array}{l}\text { Insecta - } \\
\text { Caelifera }\end{array}$ & $\begin{array}{l}\text { Crop fluid for } \\
\text { defense }\end{array}$ & $\begin{array}{l}\text { Freeman } \\
(1968)\end{array}$ \\
\hline Various species & Instecta & $\begin{array}{l}\text { Suppression of plant } \\
\text { defense }\end{array}$ & $\begin{array}{l}\text { Timisena } \\
\text { and Mikó } \\
(2017)\end{array}$ \\
\hline $\begin{array}{l}\text { Dendraster } \\
\quad \text { excentricus }\end{array}$ & $\begin{array}{l}\text { Echinodermata, } \\
\text { Echinoidea }\end{array}$ & Offending particles & $\begin{array}{l}\text { Burke } \\
(1981)\end{array}$ \\
\hline $\begin{array}{l}\text { Pleurobranchaea } \\
\text { californica }\end{array}$ & $\begin{array}{l}\text { Mollusca - } \\
\text { Gastropoda }\end{array}$ & $\begin{array}{l}\text { Experimentally } \\
\text { administered rotten } \\
\text { squid or soap } \\
\text { solution }\end{array}$ & $\begin{array}{l}\text { McClellan } \\
(1982)\end{array}$ \\
\hline
\end{tabular}

known. Sousa and Petriella (2006) suggested, that the lack of an oesophagial valve at the entrance of the pyloric stomach of the shrimp Palaemonetes argentinus may enable regurgitation. However, the mud crab, Scylla serrata has a tri-lobed valve between the short esophagus and the cardiac stomach (Barker and Gibson, 1978) but is able to regurgitate shell fragments (Hill, 1976). The regurgitation process starts with rapid waves of contraction in the posterior region of the cardiac stomach forcing food upward, while the simultaneous opening of the esophagus allows expulsion of the food (McGaw and Curtis, 2013). To facilitate food expulsion, it appears necessary to tighten the passage between stomach and midgut to avoid pressing the stomach content into the gut. Many crustaceans, like the brachyuran crabs Scylla serrata and Menippe rumphii, possess a cardio-pyloric valve separating the cardiac and pyloric regions of the stomach allowing the passage of only very small particles (Barker and Gibson, 1978; Erri Babu et al., 1982). Additional comparative studies on crustaceans, which are capable of regurgitation (Table 1) and those which are not, like the Norway lobster, $N$. norvegicus, are required to understand the behavior and physiological mechanism of regurgitation.

Our experiments also indicate that shrimps are able to empty their stomach contents selectively. Indigestible plastic fibers were evacuated faster than food. Apparently, the animals recognized that the plastic fibers did not provide nutrients and, thus, released the synthetic stomach content on average $1.4 \mathrm{~h}$ earlier than the food content. A mixture of food and fibers, however, increased the stomach evacu- ation time by $3 \mathrm{~h}$. We suggest, that the presence of plastic fibers mimics additional food, which, apparently, needs more time to be processed and digested. Consequently, the process of regurgitation seems to be linked to the sensory recognition for mechanical and chemical stimuli within the digestive organs as reported for e.g. insects (Park and Kwon, 2011).

The shrimps ingested most of the fibers along with food but only few when fibers were offered alone. This resembles natural feeding behavior where shrimps would avoid ingestion of indigestible material. However, indigestible or hardly digestible compounds of organisms such as e.g. silica shells of diatoms, chitin bristles of annelids, or calcareous shells of bivalves are inevitably ingested as part of the prey and need to be eliminated from the digestive tract. In addition to chemical and mechanical selection of food items and gastric filter-separation of chyme and solids (Saborowski, 2015), regurgitation represents another sorting mechanism to efficiently separate assimilable material from indigestible remains.

\section{Conclusions}

Regurgitation reflects an evolutionary adaptation of crustaceans to remove large indigestible natural food items from the stomach. Nowadays it may also serve as an efficient mechanism to get rid of ingested particulate anthropogenic pollutants, such as microplastic fibers. Species, which are able to extricate themselves from such a burden may have better risk scores and will be less affected by microplastic pollution than others which are not able to do so. In turn, knowledge about biological features of species, such as regurgitation or other sorting mechanisms in the digestive tract, can help to estimate the vulnerability of species to ecotoxicological threats. This issue might be of interest for various stakeholders, including aquaculture farmers and environmental policy makes and should be addressed in future environmental risk assessment strategies.

\section{Conflicts of interest}

The authors declare no conflict of interest.

\section{Funding}

This work was performed within the research program PACES II of the Helmholtz Society. It did not receive any specific grant from funding agencies in the public, commercial, or not-for-profit sectors.

\section{Acknowledgments}

Dr. Ismeni Walter helped in creating the time-lapse video sequence of the regurgitation process.

\section{Appendix A. Supplementary data}

Supplementary data to this article can be found online at https:// doi.org/10.1016/j.envpol.2019.113068.

\section{References}

Andrady, A.L., 2011. Microplastics in the marine environment. Mar. Pollut. Bull. 62 (8), 1596-1605.

Au, S.Y., Bruce, T.F., Bridges, W.C., Klaine, S.J., 2015. Responses of Hyalella azteca to acute and chronic microplastic exposures. Environ. Toxicol. Chem. 34 (11), 2564-2572.

Barker, P.L., Gibson, R., 1978. Observations on the structure of the mouthparts, histology of the alimentary tract, and digestive physiology of the mud crab Scylla serrata (Forskål) (Decapoda: Portunidae). J. Exp. Mar. Biol. Ecol. 32, 177-196. 
Barnes, D.K.A., Galgani, F., Thompson, R.C., Barlaz, M., 2009. Accumulation and fragmentation of plastic debris in global environments. Philos. Trans. R. Soc. B 364, 1985-1998.

Beninger, P.G., St-Jean, S.D., 1997. Particle processing on the labial palps of Mytilus edulis and Placopecten magellanicus (Mollusca: Bivalvia). Mar. Ecol. Prog. Ser. $147,117-127$

Beninger, P.G., Veniot, A., Poussart, Y., 1999. Principles of pseudofeces rejection on the bivalve mantle: integration in particle processing. Mar. Ecol. Prog. Ser. 178, 259-269.

Bråte, I.L.N., Hurley, R., Iversen, K., Beyer, J., Thomas, K.V., Steindal, C.C., Green, N.W., Olsen, M., Lusher, A., 2018. Mytilus spp. as sentinels for monitoring microplastic pollution in Norwegian coastal waters: a qualitative and quantitative study. Environ. Pollut. 243, 383-3993.

Browne, M.A., 2015. Sources and pathways of microplastics to habitats. In: Bergmann M., Gutow, L., Klages, M. (Eds.), Marine Anthropogenic Litter. Springer, Cham, pp. 229-244.

Burke, R.D., 1981. Structure of the digestive tract of the pluteus larva of Dendraster excentricus (Echinodermata: Echinoida). Zoomorphology 98, 209-225.

Cammaerts, R., 1995. Regurgitation behaviours in the Lasius flavus worker (Formicidae) toward the myrmecophilous beetle Claviger testaceus (Pselaphidae) and othe recipients. Behav. Process. 34, 241-264.

Cole, M., Lindeque, P., Halsband, C., Galloway, T.S., 2011. Microplastics as contaminants in the marine environment: a review. Mar. Pollut. Bull. 62, 2588-2597.

De Falco, F., Gullo, M.P., Gentile, G., Di Pace, E., Cocca, M., Gelabert, L., Brouta-Agnésa, M., Rovira, A., Escudero, R., Villalba, R., Mossotti, R., Montar solo, A., Gavignano, S., Tonin, C., Avella, M., 2018. Evaluation of microplastic release caused by textile washing processes of synthetic fabrics. Environ. Pollut. 236, 916-925

Desforges, J.-P.W., Galbraith, M., Ross, P.S., 2015. Ingestion of microplastics by zooplankton in the northeast Pacific ocean. Arch. Environ. Contam. Pollut. 69, 320-330

Devriese, L.I., van der Meulen, M.D., Maes, T., Bekaert, K., Paul-Pont, I., Frère, L., Robbens, J., Vethaak, A.D., 2015. Microplastic contamination in brown shrimp (Crangon crangon, Linnaeus 1758) from coastal waters of the southern North Sea channel area. Mar. Pollut. Bull. 98, 179-187.

Dris, R., Gasperi, J., Saad, M., Mirande, C., Tassin, B., 2016. Synthetic fibers in atmospheric fallout: a source of microplastics in the environment. Mar. Pollut. Bull. 104, 290-293.

Dris, R., Gasperi, J., Mirande, C., Mandin, C., Guerrouache, M., Langlois, V., Tassin, B., 2017. A first overview of textile fibers, including microplastics, in indoor and outdoor environments. Environ. Pollut. 221, 453-458.

Erri Babu, D., Shyamasundrari, K., Hanumantha Rao, K., 1982. Studies on the digestive system of the crab Menippe rumphii (Fabricius) (Crustacea: Brachyura). J. Exp. Mar. Biol. Ecol. 58, 175-191.

Fair, P.H., Fortner, A.R., Millikin, M.R., Sick, L.V., 1980. Effects of dietary fiber on growth, assimilation and cellulose activity of the prawn (Macrobrachium rosenbergii). Proc. World Maricult. Soc. 11, 369-381.

Forster, R.M., Gabbott, P.A., 1971. The assimilation of nutrients from compounded diets by the prawns Palaemon serratus and Pandalus platyceros. J. Mar. Biol. Assoc. U. K. 51, 943-961.

Freeman, M.A., 1968. Pharmacological properties of the regurgitated crop fluid of the African migratory locust. Locusta migratoria L. Comp. Biochem. Physiol. 26, 1041-1049.

Gewert, B., Ogonowski, M., Barth, A., MacLeod, M., 2017. Abundance and composition of near surface microplastics and plastic debris in the Stockholm Archipelago, Baltic Sea. Mar. Pollut. Bull. 120, 292-302.

Gray, A.D., Weinstein, J.E., 2017. Size- and shape-dependent effects of microplastic particles on adult daggerblade grass shrimp (Palaemonetes pugio). Environ. Toxicol. Chem. 36 (11), 3074-3080.

Haddon, M., Wear, R.G., 1987. Biology of feeding in the New Zealand paddle crab Ovalipes catharus (Crustacea, Portunidae). N. Z. J. Mar. Freshw. Res. 21, 55-64.

Hämer, J., Gutow, L., Köhler, A., Saborowski, R., 2014. Fate of microplastics in the marine isopod Idotea emarginata. Environ. Sci. Technol. 48 (22), 13451-13458.

Hill, B.J., 1976. Natural food, foregut clearance-rate and activity of the crab Scylla serrata. Mar. Biol. 34, 109-116.

Jambeck, J.R., Geyer, R., Wilcox, C., Siegler, T.R., Perryman, M., Andrady, A., Narayan, R., Law, K.L., 2015. Plastic waste inputs from land into the ocean. Science 347 (6223), 768-771.

Jemec, A., Horvat, P., Kunej, U., Bele, M., Kržan, A., 2016. Uptake and effects of microplastic textile fibres on freshwater crustacean Daphnia magna. Environ. Pollut. 219, 201-209.

Jeong, C.-B., Won, E.-J., Kang, H.-M., Lee, M.-C., Hwang, D.-S., Hwang, U.-K., Zhou, B., Souissi, S., Lee, S.-J., Lee, J.S., 2016. Microplastic size-dependence toxicity, oxidative stress induction, and p-JNK and p-p38 activation in the monogonont rotifer (Brachionus koreanus). Environ. Sci. Technol. 50 (16), 8849-8857.

Jeong, C.-B., Kang, H.-M., Lee, M.-C., Kim, D.-H., Han, J., Hwang, D.-S., Souissi, S., Lee, S.-J., Shin, K.-H., Park, H.G., Lee, J.-S., 2017. Adverse effects of microplas- tics and oxidative stress-induced MAPK/Nrf2 pathway mediated defense mechanisms in the marine copepod Paracyclopina nana. Sci. Rep. 7, 41323.

Kaposi, K.L., Mos, B., Kelaher, B.P., Dworjanyn, S.A., 2014. Ingestion of microplastic has limited impact on a marina larva. Environ. Sci. Technol. 48 (3), 1638-1645.

Lawton, P., 1989. Predatory interaction between the brachyuran crab Cancer pagurus and decapod crustacean prey. Mar. Ecol. Prog. Ser. 52, 169-179.

Macfadyen, G., Huntington, T., Cappell, R., 2009. Abandoned, lost or otherwise discarded fishing gear. UNEP Regional Seas Reports and Studies, No. 185. FAO Fisheries and Aquaculture Technical Paper, No. 523 UNEP/FAO, Rome, 115pp.

Mason, S.A., Garneau, D., Sutton, R., Chu, Y., Ehmann, K., Barnes, J., Fink, P., Papazissimos, D., Rogers, D.L., 2016. Microplastic pollution is widely detected in US municipal wastewater treatment plant effluent. Environ. Pollut. 218, 1045-1054.

Mathalon, A., Hill, P., 2014. Microplastic fibers in the intertidal ecosystem surrounding Halifax harbor, Nova Scotia. Mar. Pollut. Bull. 81, 69-79.

McClellan, A.D., 1982. Movement and motor patterns of the buccal mass of Pleurobrancaea during feeding, regurgitation and rejection. J. Exp. Biol. 98, 195-211.

McGaw, I.J., 2006. Feeding and digestion in low salinity in an osmoconforming crab, Cancer gracilis II. Gastric evacuation and motility. J. Exp. Biol. 209, 3777-3785.

McGaw, I.J., 2007. Gastric processing and evacuation during emersion in red rock crab, Cancer productus. Mar. Freshw. Behav. Physiol. 40 (2), 117-131.

McGaw, I.J., Curtis, D.L., 2013. A review of gastric processing in decapod crustaceans. J. Comp. Physiol. B 183, 443-465.

Murray, F., Cowie, P.R., 2011. Plastic contamination in the decapod crustacean Nephrops norvegicus (Linnaeus, 1758). Mar. Pollut. Bull. 62, 1207-1217.

Napper, I.E., Thompson, R.C., 2016. Release of synthetic plastic fibres from domestic washing machines: effects of fabric type and washing conditions. Mar. Pollut. Bull. 112, 39-45

Park, J.-H., Kwon, J.Y., 2011. Heterogeneous expression of Drosophila gustatory receptors in enteroendocrine cells. PLoS One 6 (12), e29022https://doi.org/10.1371/ journal.pone.0029022.

Petersen, S.C., Johnson, N.D., LeGuyader, J.L., 1987. Defense regurgitation of allochemcials derived from host cyanogenesis by eastern tent caterpillars. Ecology 68 (5), 1268-1272. https://doi.org/.

Rochman, C.M., Tahir, A., Williams, S.L., Baxa, D.V., Lam, R., Miller, J.T., The, F.-C., Werolilangi, S., The, S.J., 2015. Anthropogenic debris in seafood: plastic debris and fibers from textiles in fish and bivalves sold for human consumption. Sci. Rep. 5, 14340

Saborowski, R., 2015. Nutrition and digestion. In: Chang, E., Thiel, M. (Eds.), Natural History of the Crustacea. Vol IV Physiological Regulation. Oxford University Press, New York, pp. 285-319.

Salvador Cesa, F., Turra, A., Baruque-Ramos, J., 2017. Synthetic fibers as microplastics in the marine environment: a review from textile perspective with a focus on domestic washings. Sci. Total Environ. 598, 1116-1129.

Santana, M.F.M., Moreira, F.T., Pereira, C.D.S., Abessa, D.M.S., Turra, A., 2018. Continuous exposure to microplastics does not cause physiological effects in the cultivated mussel Perna perna. Arch. Environ. Contam. Toxicol. 74, 594-604.

Sousa, L., Petriella, A.M., 2006. Morphology and histology of $P$. argentinus (Crustacea, Decapoda, Caridea) digestive tract. Biocell 30 (2), 287-294.

Sword, G.A., 2001. Tasty on the outside, but toxic in the middle: grasshopper regurgitation and host plant-mediated toxicity to a vertebrate predator. Oecologia 128 , 416-421.

ter Halle, A., Ladirat, L., Gendre, X., Goudouneche, D., Pusineri, C., Routaboul, C., Tenailleau, C., Duployer, B., Perez, E., 2016. Understanding the fragmentation pattern of marine plastic debris. Environ. Sci. Technol. 50, 5668-5675.

Timilsena, B.P., Mikó, I., 2017. Know your insect: the structural backgrounds of regurgitation, a case study on Manduca sexta and Heliothis virescence (Lepidoptera : Sphingidae, Noctuidae). Res. Ideas Outcomes 3, e11997https://doi.org/10.3897/ rio.3.e11997.

Vadassery, J., Reichelt, M., Mithöfer, A.S., 2012. Direct proof of ingested food regurgitation by Spodoptera littoralis caterpillars during feeding on Arabidopsis. J. Chem. Ecol. 38, 865-872. https://doi.org/10.1007/s10886-012-0143-5.

von Moos, N., Burkhardt-Holm, P., Köhler, A., 2012. Uptake and effects of of microplastics on cells and tissue of the Blue mussel Mytilus edulis L. after an experimental exposure. Environ. Sci. Technol. 46 (20), 11327-11335.

Wallis, D.I., 1961. Food-sharing behaviour of the ants Formica sanguinea and Formica fusca. Behaviour 17 (1), 17-47.

Weber, A., Scherer, C., Brennholt, N., Reifferscheid, G., Wagner, M., 2018. PET microplastics do not negatively affect the survival, development, metabolism and feeding activity of the freshwater invertebrate Gammarus pulex. Environ. Pollut. 234, 181-189.

Weinstein, J.E., Crocker, B.K., Gray, A.D., 2016. From macroplastics to microplastics degradation of high-density polyethylene, polypropylene, and polystyrene in a salt marsh habitat. Environ. Toxicol. Chem. 35 (7), 1632-1640.

Welden, N.A.C., Cowie, P.R., 2016a. Environment and gut morphology influence microplastic retention in langoustine, Nephrops norvegicus. Environ. Pollut. 214, $859-865$. 
Welden, N.A.C., Cowie, P.R., 2016b. Long-term microplastic retention causes reduced body condition in the langoustine, Nephrops norvegicus. Environ. Pollut. 218, 895-900.

Wesch, C., Elert, A.M., Wörner, M., Braun, U., Klein, R., Paulus, M., 2017. Assuring quality in microplastic monitoring: about the value of clean-air devices as essentials for verified data. Sci. Rep. 7, 5424

\section{E T O C B L U R B}

The evolutionary developed process of regurgitation in shrimps provides nowadays a suitable mechanism to eliminate ingested anthropogenic mi- croplastic fibers from the stomach, avoiding accumulation and, thus, health impairment. 